Article

\title{
Experimental Design Modeling of the Effect of Hexagonal Wurtzite-ZnO Synthesis Conditions on Its Characteristics and Performance as a Cationic and Anionic Adsorbent
}

\author{
Mai M. Khalaf ${ }^{1,2}{ }^{(0}$, Enshirah Da'na ${ }^{1, *} \mathbb{C}$, Kawther Al-Amer ${ }^{1}$ and Manal Hessien ${ }^{1, *(1)}$ \\ 1 Department of Chemistry, King Faisal University, P.O. Box 400, Alahsa 31982, Saudi Arabia; \\ mmkali@kfu.edu.sa (M.M.K.); kalamer@kfu.edu.sa (K.A.-A.) \\ 2 Chemistry Department, Faculty of Science, Sohag University, Sohag 82524, Egypt \\ * Correspondence: edana@kfu.edu.sa (E.D.); mhessien@kfu.edu.sa (M.H.); \\ Tel.: +966-135897540 (E.D.); +966-135897497 (M.H.); Fax: 00966135899557 (E.D. \& M.H.)
}

Received: 11 September 2019; Accepted: 25 October 2019; Published: 28 October 2019

\begin{abstract}
Surface composite design was used to study the effect of the $\mathrm{ZnO}$ synthesis conditions on its adsorption of methyl orange (MO) and methylene blue (MB). The $\mathrm{ZnO}$ was prepared via hydrothermal treatment under different conditions including temperature $(\mathrm{T})$, precursor concentration $(\mathrm{C}), \mathrm{pH}$, and reaction time $(\mathrm{t})$. Models were built using four Design expert-11 software-based responses: the point of zero charge ( $\mathrm{pHzc}), \mathrm{MO}$ and $\mathrm{MB}$ removal efficiencies $\left(\mathrm{R}_{\mathrm{MO}}, \mathrm{R}_{\mathrm{MB}}\right), \mathrm{MO}$ and $\mathrm{MB}$ adsorption capacities $\left(\mathrm{q}_{\mathrm{MO}}, \mathrm{q}_{\mathrm{MB}}\right)$, and hydrodynamic diameter of $\mathrm{ZnO}$ particles $\left(\mathrm{D}_{\mathrm{h}}\right)$. $\mathrm{ZnO}$ was characterized by X-ray diffraction (XRD), Fourier-transform infrared (FTIR) spectroscopy, UV/VIS spectroscopy, thermal gravimetric analysis (TGA), and dynamic light scattering (DLS). The formation of ZnO was confirmed by the XRD, UV, and FTIR spectra. Results showed a very high efficiency for most of the samples for adsorption of $\mathrm{MB}$, and more than $90 \%$ removal efficiency was achieved by 8 samples among 33 samples. For MO, more than $90 \%$ removal efficiency was achieved by 2 samples among 33 samples. Overall, 26 of 31 samples showed higher MB adsorption capacity than that of MO. $R_{M B}$ was found to depend only on the synthesis temperature while $R_{M O}$ depends on temperature, $\mathrm{pH}$, and reaction time. $\mathrm{pHzc}$ was found to be affected by the synthesis $\mathrm{pH}$ only while $\mathrm{D}_{\mathrm{h}}$ depends on the synthesis $\mathrm{pH}$ and precursor concentration.
\end{abstract}

Keywords: nanoparticles; adsorption; surface composite design; $\mathrm{ZnO}$; methyl orange; methylene blue

\section{Introduction}

Metal oxides have attracted huge attention recently due to their important applications in many fields. Among them, the $\mathrm{ZnO}$ has received great attention due to attractive characteristics including its novelty, diversity, and easily controlled morphologies [1], which can be used in a wide range of applications such as drug delivery and anticancer [2], antimicrobial [3,4], photocatalysis [1,5-7], Light-emitting diode (LEDs) [8], environmental applications [8,9], solar cells [7,10], drugs, cosmetics, antibacterial coatings for fabrics, and antibacterial packaging for food [11].

These characteristics make $\mathrm{ZnO}$ a very attractive candidate for exploring new applications. However, development of $\mathrm{ZnO}$ for new applications requires the ability to control morphological structures within reasonable synthetic conditions, which is one of the biggest challenges [10]. So far, many different $\mathrm{ZnO}$ structures such as flowers [1,12], needles [12], wires [13], rods [14-16], spheres [17,18], and stars [3,19] have been reported [1]. In addition to morphological structure, it is important for some applications to be able to control band gap energy for photocatalytic 
applications [17], particle size distribution [17,20,21], and zero point charge [22] for anionic and cationic adsorption applications.

Several $\mathrm{ZnO}$ synthesis routes have been described in the literature with different morphologies and excellent characteristics, including chemical precipitation [6], solvothermal [19], sol-gel processing [7], thermal decomposition [15], microwave irradiation [5], chemical bath deposition [4], dip coating [23], spin coating [20], electrical deposition [23], and hydrothermal processing [1,12,13,18,24-26]. Among these methods, hydrothermal processing has been proven to be a flexible approach to $\mathrm{ZnO}$ synthesis due to its simplicity, ease, and relatively low fabrication cost $[11,24]$. Furthermore, it offers a path for homogeneous nucleation with high purity without the need for calcination.

Many factors have been reported to affect the properties of the synthesized $\mathrm{ZnO}$ via hydrothermal processing such as synthesis temperature [5,16,25-27], precursor concentration [6,19], $\mathrm{pH}$ of synthesis mixture $[12,13,25,26]$, and reaction time [28]. Understanding the effects of all of these factors by changing only one variable each time requires a large number of experiments, long time, and high cost. Furthermore, it is impossible to draw trustworthy conclusions regarding interactions between these factors following this research routine [24].

Design of experiments (DOE) offers the ability to improve $\mathrm{ZnO}$ characteristics, and reduces process variability, time, the number of experiments, and cost. Furthermore, DOE is very powerful in determining the extent of interactions among the studied variables [25], although, to our best knowledge, DOE methodology has very limited publications on $\mathrm{ZnO}$ applications $[26,29,30]$ and synthesis [31,32].

The toxicity and carcinogenic nature of dyes pose a risk to the environment. Furthermore, their degradation may lead to the production of carcinogenic compounds such as p-aminoazobenzene [33]. Accordingly, huge interest has been put in the development and synthesis of $\mathrm{ZnO}$ nanoparticles for removal of dyes such as methylene blue (MB) and methyl orange (MO). However, most of the reported work was dedicated to the development of $\mathrm{ZnO}$ for photocatalytic degradation of these dyes [9,26,33-36]. On the other hand, very limited reports can be found about the adsorption removal of these dyes, even though it is more advantageous over the degradation because of its low cost, simple design, and no formation of harmful by-products [29,37-42].

In our previously published work [43], one-dimensional nanorods, two-dimensional nanoflakes, and nanoplates $\mathrm{ZnO}$ were synthesized via a hydrothermal process. It was found that the growth and the morphology of nano $\mathrm{ZnO}$ were strongly affected by $\mathrm{Zn}$ concentration, $\mathrm{pH}$, temperature, and growth time. All the synthesized samples were characterized with Fourier-transform infrared (FTIR) spectroscopy, X-ray diffraction (XRD) analysis, and scanning electron microscopy (SEM). In this study, further investigation of the effects of these factors on the point of zero charge $\left(\mathrm{pH}_{\mathrm{ZC}}\right)$, hydrodynamic diameter $\left(\mathrm{D}_{\mathrm{h}}\right)$, and the cationic and anionic adsorption performance of the $\mathrm{ZnO}$ following the central composite design methodology. This statistical methodology can be applied to correlate a specific response to synthesis conditions in order to minimize process variability, cost, the number of experiments, and time. Furthermore, it is a very helpful tool in determining the magnitude of interactions among the major effects [30].

\section{Materials and Methods}

\subsection{Materials}

Zinc nitrate $\left(\mathrm{Zn}\left(\mathrm{NO}_{3}\right)_{2}\right)$, Methyl orange $\left(\mathrm{C}_{14} \mathrm{H}_{14} \mathrm{~N}_{3} \mathrm{SO}_{3} \mathrm{Na}\right.$, C.I.13025), MB $\left(\mathrm{C}_{16} \mathrm{H}_{18} \mathrm{ClN}_{3} \mathrm{~S}\right)$, and potassium hydroxide $(\mathrm{KOH})$ were bought from Sigma-Aldrich. All the primary chemicals used in this work were of analytical grade.

\subsection{Preparation of Zinc Hydroxide}

A specific amount of $\mathrm{Zn}\left(\mathrm{NO}_{3}\right)_{2}$ was weighed according to experimental design, shown in Tables 1 and 2, and then dissolved in $40 \mathrm{~mL}$ of distilled water. The mixture was stirred at $40 \mathrm{rpm}$ to ensure 
complete salt dissolving. The mixture $\mathrm{pH}$ was then adjusted by adding $1 \mathrm{M} \mathrm{KOH}$ solution dropwise at a rate of $1 \mathrm{~mL} / \mathrm{min}$ via a burette. The $\mathrm{pH}$ of the solution was monitored using an Orion 2 Star $\mathrm{pH}$ meter until the required $\mathrm{pH}$ was reached according to Tables 1 and 2.

Table 1. Independent variables and their levels used for the central composite design.

\begin{tabular}{ccccc}
\hline \multirow{2}{*}{ Variable } & Symbol & \multicolumn{3}{c}{ Level in Coded and Real Values } \\
\cline { 3 - 5 } & & $\mathbf{- 1}$ & $\mathbf{0}$ & $\mathbf{+ 1}$ \\
\hline Precursor concentration $(\mathrm{M})$ & $\mathrm{C}$ & 0.2 & 0.3 & 0.4 \\
Temperature $\left({ }^{\circ} \mathrm{C}\right)$ & $\mathrm{T}$ & 100 & 150 & 200 \\
Time $(\mathrm{h})$ & $\mathrm{t}$ & 1 & 1.5 & 2 \\
$\mathrm{pH}$ & $\mathrm{pH}$ & 7 & 9 & 11 \\
\hline
\end{tabular}

\subsection{Hydrothermal Treatment}

The $\mathrm{Zn}(\mathrm{OH})_{2}$ precipitate was transferred from the beaker to a Teflon container, sealed very well in an autoclave and then heated in an oven at the required temperature $(\mathrm{T})$ and for required time according to Tables 1 and 2 .

\subsection{Washing and Drying}

After the hydrothermal treatment, the sample was transferred from the autoclave into a beaker and the liquor (supernatant) was poured out. Then, the sample was sonicated in $50 \mathrm{~mL}$ of distilled water for $90 \mathrm{~min}$ using an ultrasonic system (Powersonic 405). After that, the sample was left to settle overnight, the liquor was then poured, and $20 \mathrm{~mL}$ of ethanol was added. The sample was again sonicated for $90 \mathrm{~min}$ and then left to settle overnight. The liquor was poured again and the sample was left in the oven overnight at $60{ }^{\circ} \mathrm{C}$ to get rid of any retained water. Finally, the samples were collected and coded according to Table 2 and kept until being used.

\subsection{Methyl Orange and Methylene Blue Solution Preparation}

Forty milligrams of $\mathrm{MO}$ or $\mathrm{MB}$ were dissolved in $1 \mathrm{~L}$ of double distilled water to prepare a 40 ppm stock solution of each. These two solutions were consecutively diluted to prepare different concentrations in a range of 5-30 ppm. Only the $20 \mathrm{ppm}$ solution was used for the adsorption tests, and the other concentrations were used for the calibration of the UV instrument before each test. $\mathrm{HNO}_{3}$ or $\mathrm{NaOH}$ was used to control the $\mathrm{pH}$ of the solutions by an Orion 2 Star $\mathrm{pH}$ meter.

\subsection{Characterization}

A high-resolution transmission electron microscope (JEOL JEM-1011 Transmission Electron Microscope) was used for TEM imaging. The Cary 630 FTIR spectrophotometer was used to collect the FTIR spectra of the ZnO samples. UV/VIS absorption was performed with the Shimadzu UV-1800 spectrophotometer. The Cilas Nano DS dual light scattering particle size analyzer was used to perform dynamic light scattering (DLS). Prior to UV and DLS, ZnO samples were sonicated in deionized, double distilled water using Powersonic 405 for $1.5 \mathrm{~h}$ at $20^{\circ} \mathrm{C}$. Structural properties of $\mathrm{ZnO}$ samples were investigated via XRD using a Burker D8 Advance XRD system with a Ni-filled Cu-K $\alpha$ radiation at a wavelength of $1.54060 \AA$. $\mathrm{ZnO}$ nanoparticles were scanned at a rate of $2.0^{\circ} / \mathrm{min}$ from $10^{\circ}$ to $60^{\circ}$. Thermal gravimetric analysis (TGA) was performed to investigate the thermal stability of the synthesized ZnO using a TA instrument model SDT Q600. Twenty milligrams of the ZnO sample was heated at a rate of $2{ }^{\circ} \mathrm{C} / \mathrm{min}$ from 25 to $1000{ }^{\circ} \mathrm{C}$ in an inert medium. The Brunauer-Emmett-Teller (BET) analysis of two selected samples 30 and 34 (best and worst adsorbents) were measured by N2 adsorption at $77 \mathrm{~K}$ using a BET surface area analyzer (Micromeritics ASAP 2020). Prior to analysis, samples were degased at $300{ }^{\circ} \mathrm{C}$ for $350 \mathrm{~min}$ of holding time to remove the impurities from the surface of the samples. 
Table 2. Independent variables and their real values and responses measured.

\begin{tabular}{|c|c|c|c|c|c|c|c|c|c|c|c|}
\hline Standard & Random & $\mathrm{C}(\mathrm{M})$ & $\mathrm{pH}$ & $\mathrm{T}\left({ }^{\circ} \mathrm{C}\right)$ & Time (h) & $\begin{array}{c}\text { Point of Zero } \\
\left.\text { Charge (pH }{ }^{\mathrm{zC}}\right)\end{array}$ & $\mathrm{D}_{\mathrm{h}}(\mathrm{nm})$ & $\begin{array}{l}\text { Adsorption Capacity } \\
\text { of } \mathrm{MB}\left(\mathrm{q}_{\mathrm{MB}} ; \mathrm{mg} / \mathrm{g}\right)\end{array}$ & 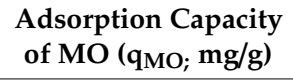 & $\begin{array}{c}\text { Removal Efficiency } \\
\text { of MO (R }\end{array}$ & $\begin{array}{c}\text { Removal Efficiency } \\
\text { of MB }\left(\mathrm{R}_{\mathrm{MB}} ; \%\right)\end{array}$ \\
\hline 1 & 27 & 0.2 & 7 & 100 & 1 & 7.3 & 279 & 5.15 & 5.78 & 72.30 & 64.41 \\
\hline 2 & 6 & 0.4 & 7 & 100 & 1 & 5.9 & 1322 & 6.06 & 7.28 & 91.00 & 75.72 \\
\hline 3 & 8 & 0.2 & 11 & 100 & 1 & 6.8 & 350 & 7.22 & 4.74 & 59.20 & 90.26 \\
\hline 4 & 23 & 0.4 & 11 & 100 & 1 & 6.8 & 318 & 6.94 & 3.86 & 48.20 & 86.77 \\
\hline 5 & 30 & 0.2 & 7 & 200 & 1 & 6.7 & 537 & 6.38 & 5.46 & 68.20 & 79.76 \\
\hline 6 & 5 & 0.4 & 7 & 200 & 1 & 6 & 642 & 7.05 & 4.63 & 57.86 & 88.15 \\
\hline 7 & 20 & 0.2 & 11 & 200 & 1 & 6.9 & 242 & 2.87 & 0.35 & 4.37 & 35.92 \\
\hline 8 & 26 & 0.4 & 11 & 200 & 1 & 6.8 & 311 & 2.23 & 0.17 & 2.18 & 27.83 \\
\hline 9 & 28 & 0.2 & 7 & 100 & 2 & 6.5 & 280 & 8.00 & 5.96 & 74.56 & 100.00 \\
\hline 10 & 7 & 0.4 & 7 & 100 & 2 & 7.2 & 412 & 6.57 & 7.66 & 95.75 & 82.09 \\
\hline 11 & 12 & 0.2 & 11 & 100 & 2 & 7.2 & 218 & 2.83 & 0.60 & 7.52 & 35.38 \\
\hline 12 & 1 & 0.4 & 11 & 100 & 2 & 7.9 & 536 & 4.45 & 2.24 & 28.05 & 55.60 \\
\hline 13 & 10 & 0.2 & 7 & 200 & 2 & 7.2 & 824 & 0.68 & 0.42 & 5.20 & 8.51 \\
\hline 14 & 14 & 0.4 & 7 & 200 & 2 & 6.8 & 752 & 4.39 & 2.13 & 26.59 & 54.83 \\
\hline 15 & 2 & 0.2 & 11 & 200 & 2 & 6.8 & 247 & 0.93 & 0.37 & 4.60 & 11.58 \\
\hline 16 & 4 & 0.4 & 11 & 200 & 2 & 7.2 & 366 & 3.94 & 1.12 & 14.01 & 49.29 \\
\hline 17 & 33 & 0.1 & 9 & 150 & 1.5 & 7.3 & 647 & 7.82 & 5.57 & 69.59 & 97.74 \\
\hline 18 & 24 & 0.5 & 9 & 150 & 1.5 & 7.2 & 1252 & 7.17 & 6.39 & 79.87 & 89.65 \\
\hline 19 & 29 & 0.3 & 5 & 150 & 1.5 & \multicolumn{6}{|c|}{ No precipitation was observed } \\
\hline 20 & 25 & 0.3 & 13 & 150 & 1.5 & 8 & 8920 & 0.00 & 0.91 & 11.39 & 0.00 \\
\hline 21 & 11 & 0.3 & 9 & 50 & 1.5 & 6.7 & 260 & 7.21 & 5.11 & 63.83 & 90.10 \\
\hline 22 & 9 & 0.3 & 9 & 250 & 1.5 & 8.1 & 435 & 1.49 & 0.62 & 7.80 & 18.61 \\
\hline 23 & 34 & 0.3 & 9 & 150 & 0.5 & 6.8 & 352 & 6.96 & 5.26 & 65.72 & 86.94 \\
\hline 24 & 13 & 0.3 & 9 & 150 & 2.5 & 7.6 & 262 & 6.93 & 3.52 & 44.03 & 86.69 \\
\hline 25 & 18 & 0.3 & 9 & 150 & 1.5 & 6.6 & 397 & 6.96 & 4.31 & 53.86 & 86.98 \\
\hline 26 & 22 & 0.3 & 9 & 150 & 1.5 & 6.6 & 462 & 6.68 & 4.71 & 58.92 & 83.45 \\
\hline 27 & 32 & 0.3 & 9 & 150 & 1.5 & 7.2 & 1475 & 6.48 & 5.36 & 67.06 & 80.98 \\
\hline 28 & 21 & 0.3 & 9 & 150 & 1.5 & 6.6 & 417 & 7.24 & 4.83 & 60.43 & 90.54 \\
\hline 29 & 15 & 0.3 & 9 & 150 & 1.5 & 7.1 & 437 & 7.86 & 4.51 & 56.32 & 98.30 \\
\hline 30 & 3 & 0.3 & 7 & 150 & 1.5 & 7.2 & 851 & 8.00 & 6.24 & 77.95 & 100.00 \\
\hline 31 & 19 & 0.3 & 11 & 150 & 1.5 & 8.1 & 373 & 4.70 & 1.71 & 21.41 & 58.74 \\
\hline 32 & 16 & 0.4 & 9 & 150 & 1.5 & 6.9 & 472 & 7.86 & 5.16 & 64.48 & 98.19 \\
\hline 33 & 17 & 0.2 & 9 & 150 & 1.5 & 7 & 497 & 6.44 & 5.03 & 62.93 & 80.49 \\
\hline 34 & 31 & 0.3 & 9 & 250 & 2.5 & 6.5 & 937 & 0.24 & 0.62 & 7.76 & 3.05 \\
\hline
\end{tabular}




\subsection{Point of Zero Charge}

The $\mathrm{pH}_{\mathrm{ZC}}$ of the synthesized $\mathrm{ZnO}$ was determined following the procedure reported elsewhere [44]: 8 beakers, each containing $20 \mathrm{~mL}$ of $0.1 \mathrm{M} \mathrm{NaCl}$ solution. The initial $\mathrm{pH}\left(\mathrm{pH}_{\mathrm{i}}\right)$ of each beaker was adjusted at a certain value within a range of 2-11 using $\mathrm{HNO}_{3}$ and $\mathrm{NaOH}$ with an Orion 2 Star $\mathrm{pH}$ meter. Then, $10 \mathrm{mg}$ of the $\mathrm{ZnO}$ sample were stirred in each beaker for $24 \mathrm{~h}$ at $120 \mathrm{rpm}$ and $293 \mathrm{~K}$. Finally, samples were filtered and the final $\mathrm{pH}\left(\mathrm{pH}_{\mathrm{e}}\right)$ was determined.

\subsection{Adsorption Tests}

$\mathrm{MO}$ and $\mathrm{MB}$ adsorption was performed by mixing $0.025 \mathrm{~g}$ of $\mathrm{ZnO}$ with $10 \mathrm{~mL}$ of $20-\mathrm{ppm}$ solution for $24 \mathrm{~h}$ at $293 \mathrm{~K}$ and $140 \mathrm{rpm}$. The $\mathrm{MB} \mathrm{pH}$ was controlled at 4.5 using $\mathrm{HNO}_{3}$, while $\mathrm{MO}$ solution $\mathrm{pH}$ was 8.0 without adjustment. The residual MO and MB in the solution were detected with the Shimadzu UV-1800 spectrophotometer at $\lambda_{\max }$ of $464 \mathrm{~nm}$ for $\mathrm{MO}$ and $664 \mathrm{~nm}$ for MB, and the following equation was used to calculate the removal efficiency:

$$
R=\frac{C_{i}-C_{e}}{C_{i}} \times 100,
$$

where $C_{i}$ and $C_{e}$ are the initial and equilibrium concentrations of dye in ppm, respectively.

It is worth mentioning that the models presented in Table 3 are assuming a constant variance and time independence. Consequently, experimental runs randomization was essential. The $\mathrm{ZnO}$ synthesis conditions and their levels are shown in Table 1 as coded and real values, while Table 2 shows the detailed experimental runs with their random run order and all the measured responses.

Accordingly, it was important to test that the models have met these assumptions via residual plots. Residuals are the differences between the fitted and the observed responses. For model adequacy, it is important for any measured response to have a normal distribution of residuals probability. Moreover, for model adequacy, the residual versus the run order plot should not reveal any pattern.

\section{Results and Discussion}

The XRD pattern of a representative sample of the synthesized $\mathrm{ZnO}$ nanoparticles is shown in Figure 1a. The diffraction peaks at $2 \theta$ values of $31.73^{\circ}, 34.44^{\circ}, 36.21^{\circ}, 47.49^{\circ}$, and $56.67^{\circ}$ corresponding to miller indices of 100, 002,101,102, and 110, respectively, confirm the formation of hexagonal wurtzite phase of $\mathrm{ZnO}$ according to the standard JCPDS 80-0075. All the synthesized $\mathrm{ZnO}$ samples have a similar pattern and are available at our previously published work [43].

The TGA and DTA analyses (Figure $1 \mathrm{~b}$ ) revealed that the $\mathrm{ZnO}$ lost about $1 \%$ of its weight when the temperature reached $104{ }^{\circ} \mathrm{C}$, which may be related to the desorption of $\mathrm{CO}_{2}$ and $\mathrm{H}_{2} \mathrm{O}$ attached to the surface, and $2 \%$ weight loss of the total weight occurred at about $130{ }^{\circ} \mathrm{C}$, which is related to strongly bonded water. The maximum rate of weight loss was $0.2 \% / \mathrm{min}$, at which $8 \%$ loss of material occurred at around $692{ }^{\circ} \mathrm{C}$. The exothermic peak at $692{ }^{\circ} \mathrm{C}$ in the DTA curve is a result of the decomposition of traces of $\mathrm{Zn}(\mathrm{OH})_{2}$ existing in the sample [45]. These results reveal a good thermal stability of the sample.

Ten milligrams of each $\mathrm{ZnO}$ sample were added to $10 \mathrm{~mL}$ of deionized water and then sonicated using Powersonic 405. The solution was then used to perform the UV-VIS measurement. ZnO formation was confirmed by the appearance of absorption bands in a range of 358-380 nm, as shown in Figure 1c, for a representative sample (spectra of the rest of the samples are available in Figure S1 in Supplementary Materials). Bodke et al. reported peaks at 363 and $361 \mathrm{~nm}$ [46]. Khorsand et al. and Liang et al. recorded a characteristic absorption peak of $\mathrm{ZnO}$ at a wavelength of $375 \mathrm{~nm}[17,21]$. Ibupoto et al. reported absorption peaks of $\mathrm{ZnO}$ at wavelengths of 382 and $385 \mathrm{~nm}$ [27]. Ali et al. reported a peak at $380 \mathrm{~nm}$ [5]. Andrade et al. [3] reported $\mathrm{ZnO}$ with hexagonal wurtzite phase with absorption bands in a range of $424-433 \mathrm{~nm}$. Anandan et al. [6] reported absorption spectra of $\mathrm{ZnO}$ synthesized under different concentrations and found that the precursor concentration has an important effect on the 
adsorption characteristics. The absorption band they reported was in a range of $364-380 \mathrm{~nm}$, which is a characteristic of the $\mathrm{ZnO}$ hexagonal phase. All these reported results confirmed that the samples prepared in this work are all $\mathrm{ZnO}$ with good crystallinity of the $\mathrm{ZnO}$ with minimal impurity [5,6].

The FTIR spectra of all the prepared samples were recorded in the range from 4000 to $400 \mathrm{~cm}^{-1}$ to detect the functional groups, confirming the existence of $\mathrm{ZnO}$. All samples exhibited a similar spectra as presented in Figure 1d (spectra of other samples are available in Figure S2 in Supplementary Materials), which shows a band at $823 \mathrm{~cm}^{-1}$ due to hydrogen-bonded $\mathrm{O}-\mathrm{H}$ stretch. In addition, the band at $1640 \mathrm{~cm}^{-1}$ resulted from the $\mathrm{CO}_{2}$ adsorbed on the $\mathrm{ZnO}$ surface during storage [23]. Absorption bands at 1050 and $3480 \mathrm{~cm}^{-1}$ related to $\mathrm{CO}_{2}(\mathrm{C}-\mathrm{O})$ and $\mathrm{H}_{2} \mathrm{O}(\mathrm{O}-\mathrm{H})$ adsorbed on the surface $[21,33,34]$. The sharp, intense peaks at 420 and $406 \mathrm{~cm}^{-1}$ are related to the $\mathrm{ZnO}$ which appeared in all samples, confirming that the prepared samples were $\mathrm{ZnO}[3,5,6]$. Furthermore, $\mathrm{ZnO}$ stretching absorption was detected in all samples at around $642 \mathrm{~cm}^{-1}$ and $887 \mathrm{~cm}^{-1}$ [46].

The nitrogen adsorption isotherms for one of the best adsorbent (sample 30) and one of the worst adsorbent (sample 34) are presented in Figure 1e and the pore size distributions of the two samples are shown in Figure 1f. It is worth mentioning that complex porous materials may reveal structures from multiple isotherm types according to its pore characteristics [47]. Sample 34 shows an open hysteresis with the desorption curve lower than the adsorption curve, which is most likely due to one of the following reasons: (i) the presence of irregular microspores or bottle-shaped pores; (ii) a porous defect of the porous sample; (iii) slow penetration of the $\mathrm{N}_{2}$ molecules into very narrow pores, resulting in non-establishment of thermodynamic equilibration on any part of the adsorption-desorption isotherm; and (iv) pore blocking or cavitation associated $[47,48]$.

Sample 30 exhibited a surface area of $13.8 \mathrm{~m}^{2} \mathrm{~g}^{-1}$ and a pore size of $4.83 \mathrm{~nm}$, while sample 34 exhibited a higher surface area of $51.6 \mathrm{~m}^{2} \mathrm{~g}^{-1}$ but a smaller pore size of $3.81 \mathrm{~nm}$. The differences of surface areas and pore size are most likely associated with the crystalline structure of the two samples. For large molecules like dyes, the size of a molecule may control the diffusion in the bulk and within the pores of the adsorbent [47]. If the pore size of the adsorbent is close to the size of the adsorbate molecule, the adsorption process will be controlled by diffusion within the pores. Accordingly, the pore size of the adsorbent become more important than the surface area, since the majority of the surface area are located inside the pores, which means that if the molecules cannot diffuse inside the pores this surface area will not be available for adsorption. This explains why sample 30 has better performance than sample 34, even if it has a lower surface area.

Figure 2 displays the SEM and TEM images of some ZnO samples prepared under different conditions. It is obvious that different morphologies such as short nanorods, elliposoidal rods, irregular nanoflakes, and nanoplates with wide and narrow pore size distributions were obtained under different synthesis conditions. Figure $2 \mathrm{~d}$,e, for example, shows the effect of fabrication temperature. At $50^{\circ} \mathrm{C}$ (Figure 2d), nanoplates were obtained. Increasing the temperature to $150{ }^{\circ} \mathrm{C}$ changes the morphology into shorter nanorods (Figure 2e), as shown in TEM images Figure 2g,h. Figure 2a,b,e show the effect of the $\mathrm{Zn}$ precursor concentration. Short nanorods were observed at $0.1 \mathrm{M}$ (Figure 2a). Increasing the concentration to $0.3 \mathrm{M}$ increased the diameter of the obtained nanorods (Figure 2e). At $0.5 \mathrm{M}$ concentration, both nanorods and nanoflakes were formed. Figure 2c,e,f show the effect of synthesis $\mathrm{pH}$. At $\mathrm{pH}=7$ (Figure 2f), nanorods were formed. By increasing the $\mathrm{pH}$ to 9 (Figure 2e), nanoplates and short nanorods were formed. At $\mathrm{pH}=11$ (Figure 2c), an ellipsoidal shape with tapered tops were formed. More detailed discussion about the effect of synthesis conditions on the morphology of $\mathrm{ZnO}$ can be found in our previous contribution [43]. 

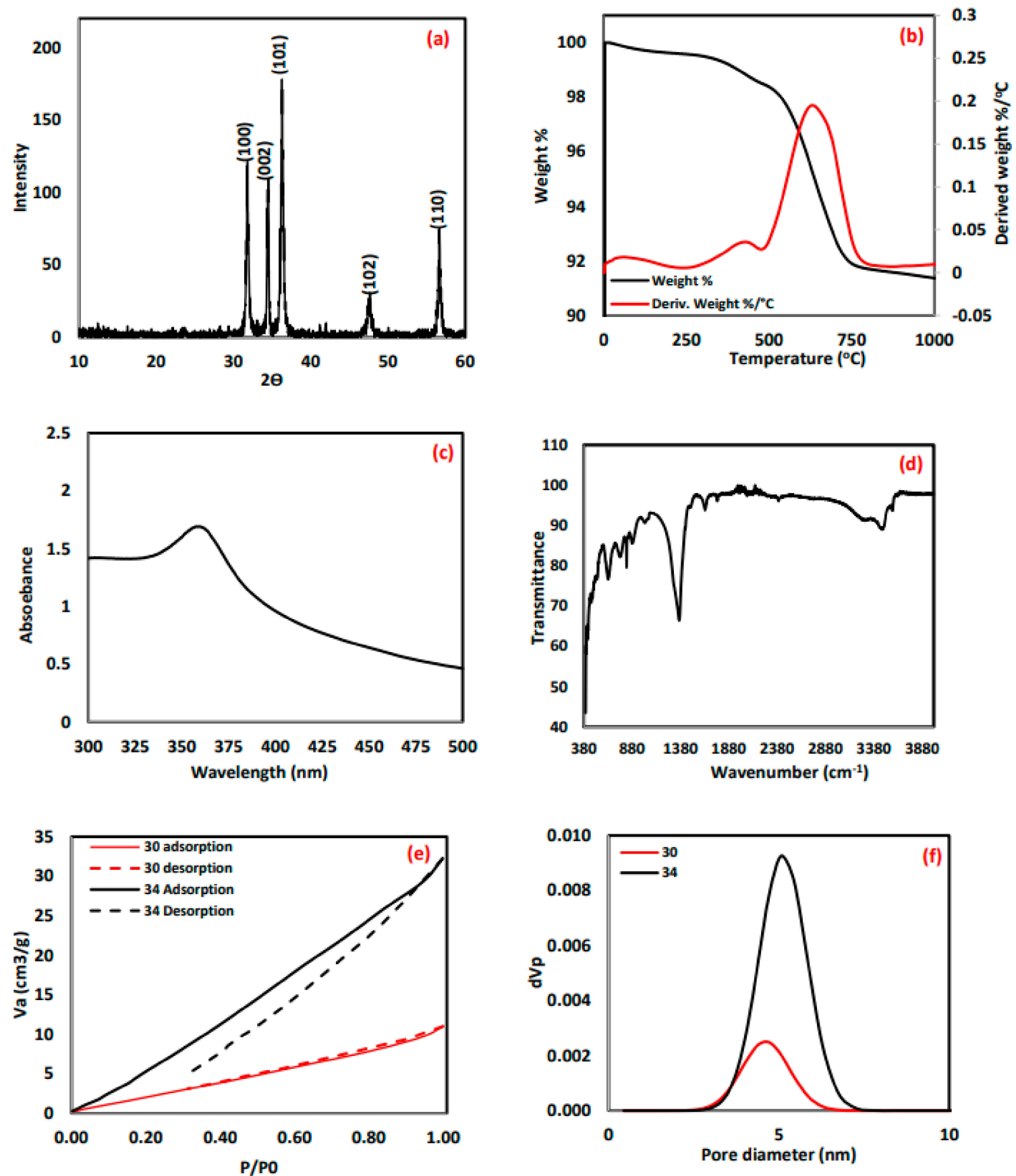

Figure 1. (a) XRD pattern of sample 31 prepared under the conditions of $\mathrm{C}=0.2 \mathrm{M}, \mathrm{pH}=7, \mathrm{~T}=100^{\circ} \mathrm{C}$, and $t=1 \mathrm{~h}$. (b) Thermal gravimetric analysis (TGA) and DTA analysis results of sample 10 prepared under the conditions of $\mathrm{C}=0.4 \mathrm{M}, \mathrm{pH}=7, \mathrm{~T}=100^{\circ} \mathrm{C}$, and $\mathrm{t}=2 \mathrm{~h}$. (c) UV-VIS spectrum of sample 1 prepared under the conditions of $\mathrm{C}=0.3 \mathrm{M}, \mathrm{pH}=11, \mathrm{~T}=150{ }^{\circ} \mathrm{C}$, and $\mathrm{t}=1.5 \mathrm{~h}$. (d) FTIR spectrum for the range of $4000-400 \mathrm{~cm}^{-1}$ of sample 1 prepared under the conditions of $\mathrm{C}=0.2 \mathrm{M}, \mathrm{pH}=7$, $\mathrm{T}=100^{\circ} \mathrm{C}$, and $\mathrm{t}=1 \mathrm{~h}$. (e) Nitrogen adsorption desorption isotherms for samples 30 and 34 . (f) Pore size distributions for samples 30 and 34 . 

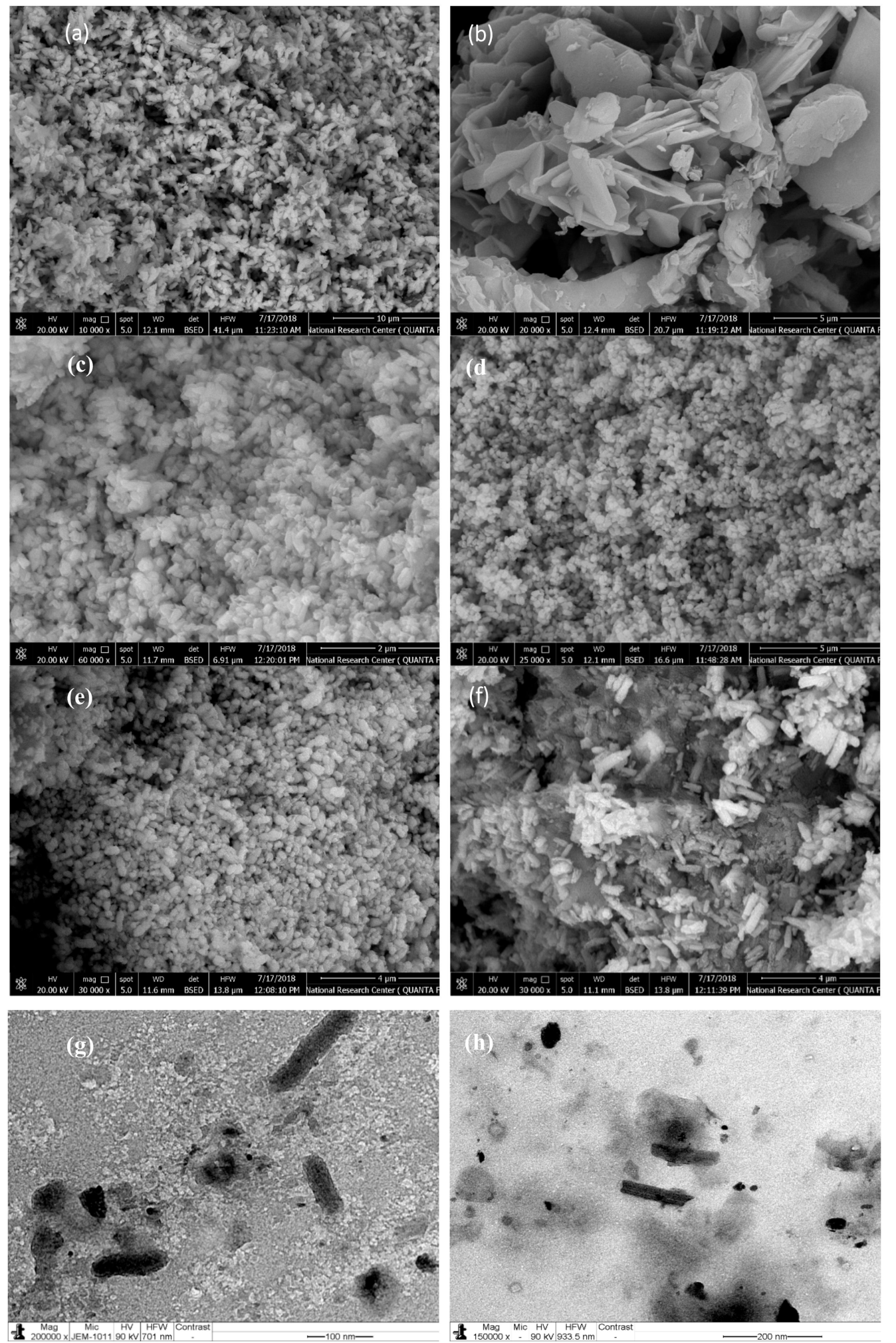

Figure 2. FE-SEM images of $\mathrm{ZnO}$ samples prepared under different conditions: (a) $\mathrm{C}=0.1 \mathrm{M}, \mathrm{pH}=9$, $\mathrm{T}=150{ }^{\circ} \mathrm{C}$, and $\mathrm{t}=1.5 \mathrm{~h}$; (b) $\mathrm{C}=0.5 \mathrm{M}, \mathrm{pH}=9, \mathrm{~T}=150{ }^{\circ} \mathrm{C}$, and $\mathrm{t}=1.5 \mathrm{~h}$; (c) $\mathrm{C}=0.3 \mathrm{M}, \mathrm{pH}=11$, $\mathrm{T}=150{ }^{\circ} \mathrm{C}$, and $\mathrm{t}=1.5 \mathrm{~h} ;(\mathbf{d}) \mathrm{C}=0.3 \mathrm{M}, \mathrm{pH}=9, \mathrm{~T}=50^{\circ} \mathrm{C}$, and $\mathrm{t}=1.5 \mathrm{~h} ;(\mathbf{e}) \mathrm{C}=0.3 \mathrm{M}, \mathrm{pH}=9, \mathrm{~T}=150{ }^{\circ} \mathrm{C}$, and $\mathrm{t}=1.5 \mathrm{~h}$; (f) $\mathrm{C}=0.3 \mathrm{M}, \mathrm{pH}=7, \mathrm{~T}=150{ }^{\circ} \mathrm{C}$, and $\mathrm{t}=1.5 \mathrm{~h}$. (g) TEM images of $\mathrm{ZnO}$ sample prepared under the conditions of $\mathrm{C}=0.3 \mathrm{M}, \mathrm{pH}=9, \mathrm{~T}=150^{\circ} \mathrm{C}$, and $\mathrm{t}=1.5 \mathrm{~h}$; (h) TEM images of $\mathrm{ZnO}$ sample prepared under the conditions of $\mathrm{C}=0.3 \mathrm{M}, \mathrm{pH}=9, \mathrm{~T}=150^{\circ} \mathrm{C}$, and $\mathrm{t}=1.5 \mathrm{~h}$. 
The $\mathrm{D}_{\mathrm{h}}$ of the $\mathrm{ZnO}$ obtained by the DLS method is shown in Figure 3. The results show that the $\mathrm{D}_{\mathrm{h}}$ of the $\mathrm{ZnO}$ prepared varies within a range from 218 to $8920 \mathrm{~nm}$.
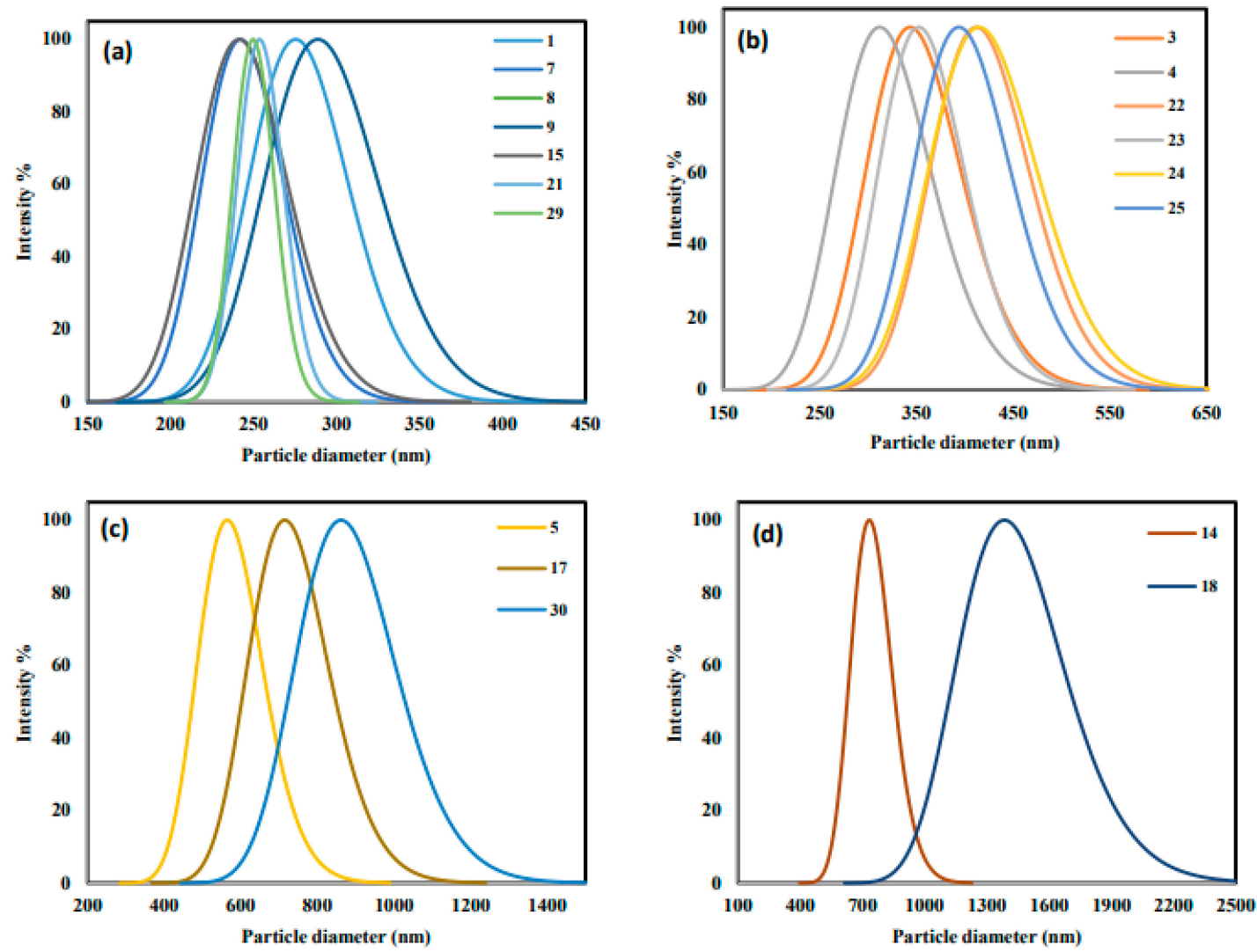

Figure 3. ZnO particle size distribution obtained from dynamic light scattering (DLS) for samples 1, 7, 8, 9, 15, 21, and 21 (a), samples 3, 4, and 22-25 (b), samples 5, 7, and 30 (c), samples 8 and 14 (d). Details of each sample synthesis conditions can be found in Table 2.

$\mathrm{ZnO}$ nanoparticles synthesis generally involves nucleation and crystal growth. Let us start with the formation of nuclei unit $\left(\mathrm{Zn}(\mathrm{OH})_{2}\right)$ and the growth unit $\left(\left[\mathrm{Zn}(\mathrm{OH})_{4}\right]^{2-}\right.$, according to the following equations [49,50]:

$$
\begin{gathered}
\mathrm{Zn}^{2+}+2 \mathrm{OH}^{-} \leftrightarrow \mathrm{Zn}(\mathrm{OH})_{2}, \\
\mathrm{Zn}^{2+}+4 \mathrm{OH}^{-} \leftrightarrow\left[\mathrm{Zn}(\mathrm{OH})_{4}\right]^{2-}, \\
{\left[\mathrm{Zn}(\mathrm{OH})_{4}\right]^{2-} \leftrightarrow \mathrm{Zn}(\mathrm{OH})_{2}+2 \mathrm{OH}^{-},} \\
\mathrm{Zn}(\mathrm{OH})_{2} \leftrightarrow \mathrm{ZnO}+\mathrm{H}_{2} \mathrm{O}, \\
{\left[\mathrm{Zn}(\mathrm{OH})_{4}\right]^{2-} \leftrightarrow \mathrm{ZnO}+\mathrm{H}_{2} \mathrm{O}+2 \mathrm{OH}^{-} .}
\end{gathered}
$$

The $\mathrm{D}_{\mathrm{h}}$ of the synthesized $\mathrm{ZnO}$ is controlled by both nucleation and crystal growth [51,52]. According to Equations (2) and (3), $\mathrm{Zn}(\mathrm{OH})_{2}$ and $\left[\mathrm{Zn}(\mathrm{OH})_{4}\right]^{2-}$ coexist in equilibrium. When $\mathrm{Zn}(\mathrm{OH})_{2}$ nuclei exist in a large amount and the growth unit $\left[\mathrm{Zn}(\mathrm{OH})_{4}\right]^{2-}$ exists in a small amount, the nucleation rate will be higher than the crystal growth rate. Accordingly, relatively small particles are obtained. Conversely, when the growth unit $\left[\mathrm{Zn}(\mathrm{OH})_{4}\right]^{2-}$ exists in a large amount and $\mathrm{Zn}(\mathrm{OH})_{2}$ nuclei exists in a small amount, the nucleation rate will be slower than the crystal growth rate, and thus, relatively large particles are obtained [52].

The equilibrium between $\mathrm{Zn}(\mathrm{OH})_{2}$ and $\left[\mathrm{Zn}(\mathrm{OH})_{4}\right]^{2-}$ is controlled by the synthesis conditions, such as the temperature, the $\mathrm{pH}$, and the $\mathrm{OH}: \mathrm{Zn}^{2+}$ ratio. $\mathrm{Zn}(\mathrm{OH})_{2}$ in the solution dissolves to $\mathrm{Zn}^{2+}$ and $\mathrm{OH}^{-}$till the concentrations of $\mathrm{Zn}^{2+}$ and $\mathrm{OH}^{-}$reach a certain critical values, and then crystallization 
of $\mathrm{ZnO}$ from the solution occurs and begin to grow, according to Equations (4) and (5). Since $\mathrm{ZnO}$ is much less soluble than $\mathrm{Zn}(\mathrm{OH})_{2}, \mathrm{Zn}(\mathrm{OH})_{2}$ tends to convert into $\mathrm{ZnO}$ [49].

Increasing synthesis temperature increases $\mathrm{ZnO}$ solubility and thus results in dissolving crystals. As a result, small crystals disappear from the solution while the large ones slightly reduced in size. Accordingly, smaller particle size distributions may be obtained by increasing the hydrothermal temperature [49].

A similar range of particle size was obtained by changing the time from 0.5 to $2.5 \mathrm{~h}$. However, changing the concentration from 0.1 to $0.5 \mathrm{M}$ resulted in a particle size within a range from $430 \mathrm{~nm}$ to $1250 \mathrm{~nm}$. Similarly, changing $\mathrm{pH}$ within a range of $7-11$ had a great impact on the particle size with a varied range of $375-850 \mathrm{~nm}$. As discussed earlier, the $\mathrm{Zn}(\mathrm{OH})_{2}:\left[\mathrm{Zn}(\mathrm{OH})_{4}\right]^{2-}$ ratio is strongly affected by the $\mathrm{pH}$ and $\mathrm{OH}: \mathrm{Zn}^{2+}$ ratio. Accordingly, both nucleation and growth rates are affected by $\mathrm{C}$ and $\mathrm{pH}$. However, the model shown in Table 3 indicates that the $\mathrm{D}_{\mathrm{h}}$ is only significantly affected by the precursor concentration and the synthesis $\mathrm{pH}$ and that the effects of both temperature and time are negligible.

Table 3. The point of zero charge ( $\mathrm{pHzc}$ ), methyl orange (MO) and methylene blue (MB) removal efficiencies ( $\mathrm{R}_{\mathrm{MO}}$ and $\mathrm{R}_{\mathrm{MB}}$, respectively), $\mathrm{MO}$ and $\mathrm{MB}$ adsorption capacities ( $\mathrm{q}_{\mathrm{MO}}$ and $\mathrm{q}_{\mathrm{MB}}$, respectively), and hydrodynamic diameter of $\mathrm{ZnO}$ particles $\left(\mathrm{D}_{\mathrm{h}}\right)$ and their models summary.

\begin{tabular}{|c|c|c|c|c|c|c|c|}
\hline \multirow{2}{*}{$\mathrm{D}_{\mathrm{h}}$} & R-sq & R-sq (adj) & R-sq (pred) & F-value & $P$-value & Residual F & Residual P \\
\hline & 0.3369 & 0.2858 & 0.1332 & 6.60 & 0.0048 & 78.23 & 0.0891 \\
\hline \multicolumn{2}{|c|}{ Uncoded equation: } & \multicolumn{6}{|c|}{$\mathrm{D}_{\mathrm{h}}=+913.86185+1102.69231 \mathrm{C}-81.56481 \mathrm{pH}$} \\
\hline \multicolumn{2}{|l|}{ Coded equation: } & \multicolumn{5}{|c|}{$\mathrm{D}_{\mathrm{h}}=+510.59+110.27 \mathrm{C}-163.13 \mathrm{pH}$} & \\
\hline \multirow{2}{*}{$\mathrm{pH}_{\mathrm{ZC}}$} & R-sq & R-sq (adj) & R-sq (pred) & F-value & $P$-value & Residual F & Residual P \\
\hline & 0.1711 & 0.1425 & 0.0450 & 5.99 & 0.0207 & 2.45 & 0.3313 \\
\hline \multicolumn{2}{|c|}{ Uncoded equation: } & \multicolumn{6}{|c|}{$\mathrm{pH}_{\mathrm{ZC}}=+5.85612+0.128835 \mathrm{pH}$} \\
\hline \multicolumn{2}{|l|}{ Coded equation: } & \multicolumn{5}{|c|}{$\mathrm{pH}_{\mathrm{ZC}}=+7.02+0.2577 \mathrm{pH}$} & \\
\hline \multirow{2}{*}{$\mathbf{R}_{\mathrm{MO}}$} & R-sq & R-sq (adj) & R-sq (pred) & F-value & $P$-value & Residual F & Residual P \\
\hline & 0.7331 & 0.6920 & 0.6410 & 23.30 & $<0.0001$ & 5.91 & 0.1548 \\
\hline \multicolumn{2}{|c|}{ Uncoded equation: } & \multicolumn{6}{|c|}{$\mathrm{R}_{\mathrm{MO}}=+212.48271-10.319 \mathrm{pH}-0.326843 \mathrm{~T}-14.75094 \mathrm{t}$} \\
\hline \multicolumn{2}{|l|}{ Coded equation: } & \multicolumn{5}{|c|}{$\mathrm{R}_{\mathrm{MO}}=+48.46-20.64 \mathrm{pH}-16.34 \mathrm{~T}-7.38 \mathrm{t}$} & \\
\hline \multirow{2}{*}{$\mathbf{R}_{\mathbf{M B}}$} & R-sq & R-sq (adj) & R-sq (pred) & F-value & P-value & Residual F & Residual $\mathbf{P}$ \\
\hline & 0.3453 & 0.2478 & 0.3220 & 14.77 & 0.0006 & 7.338 .59 & 0.1094 \\
\hline Uncoded equation: & \multicolumn{7}{|c|}{$\mathrm{R}_{\mathrm{MB}}=+123.11199-0.363235 \mathrm{~T}$} \\
\hline Coded equation: & \multicolumn{7}{|c|}{$\mathrm{R}_{\mathrm{MB}}=+68.63-18.16 \mathrm{~T}$} \\
\hline \multirow{2}{*}{ qMO } & R-sq & R-sq (adj) & R-sq (pred) & F-value & $P$-value & Residual F & Residual P \\
\hline & 0.7185 & 0.6847 & 0.6301 & 21.27 & $<0.0001$ & 93.15 & 0.0817 \\
\hline Uncoded equation: & \multicolumn{7}{|c|}{$\mathrm{q}_{\mathrm{MO}}=+17.08333-0.84444 \mathrm{pH}-0.026065 \mathrm{~T}-1.17318 \mathrm{t}$} \\
\hline Coded equation: & \multicolumn{7}{|c|}{$\mathrm{q}_{\mathrm{MO}}=+3.81-1.69 \mathrm{pH}-1.3 \mathrm{~T}-0.5866 \mathrm{t}$} \\
\hline \multirow{2}{*}{ qMB } & R-sq & R-sq (adj) & R-sq (pred) & F-value & $P$-value & Residual F & Residual P \\
\hline & 0.3467 & 0.3226 & 0.2482 & 14.33 & 0.0008 & 10.45 & 0.2404 \\
\hline Uncoded equation: & \multicolumn{7}{|c|}{$\mathrm{q}_{\mathrm{MB}}=+9.80868-0.029016 \mathrm{~T}$} \\
\hline Coded equation: & \multicolumn{7}{|c|}{$\mathrm{q}_{\mathrm{MB}}=+5.46-1.45 \mathrm{~T}$} \\
\hline
\end{tabular}

* Detailed model equations and calculations can be found in Supplementary Materials. 
The F-value of 6.60 (Table 3) indicated a significant model with only a $0.48 \%$ chance that this value could occur due to noise. A lack of fit F-value of 78.23 suggests there is a $8.91 \%$ chance that this value is due to noise. The adjusted $R^{2}$ value of 0.2858 is in good agreement with the predicted $R^{2}$ value of 0.1332 with a difference less than 0.2 .

To further ensure the model adequacy, residual plots were prepared and are shown in Figure 4. The model reliability can be confirmed, as the residual plot follows a normal distribution (Figure 4a) with a structure of less distribution when plotted against predicted values (Figure 4b).

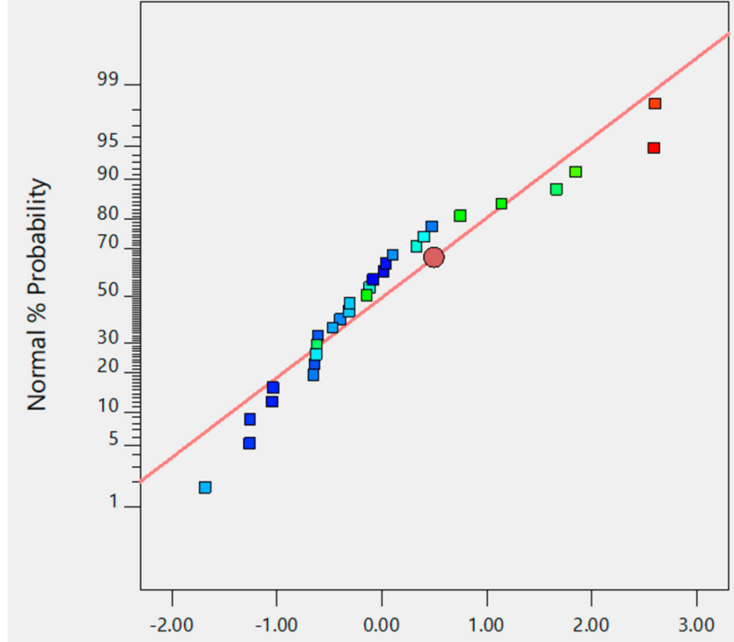

(a) Externally Studentized Residuals

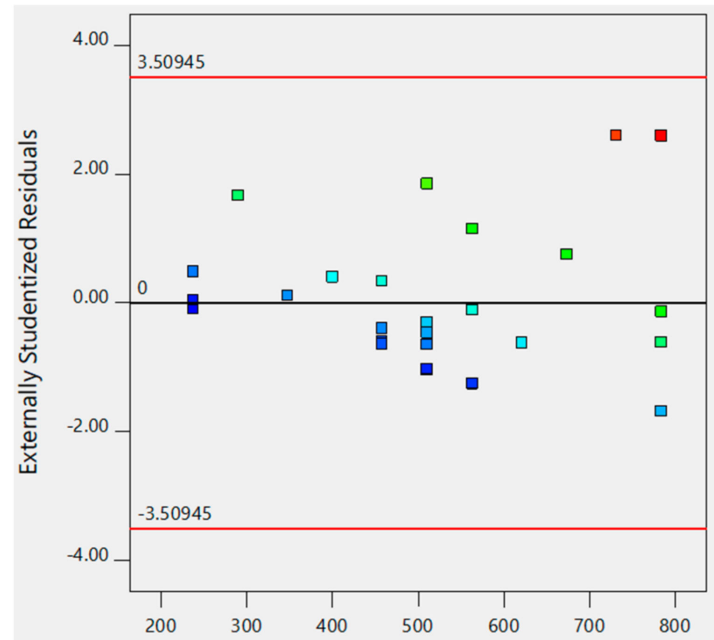

(b)

Predicted

Figure 4. Model adequacy tests for $D_{h}$ response: Normal probability of the externally studentized residuals (a), Predicted versus externally studentized residuals (b).

The obtained $\mathrm{pH}_{\mathrm{ZC}}$ values of all samples are within a range of 5.9-8.1, as shown in Table 2. It is clear that the $\mathrm{ZnO}$ surface stoichiometry was affected by the synthesis conditions and even the $\mathrm{ZnO}$ surface purity and water content could be affected [53]. This was also detected by the FTIR analysis as $\mathrm{CO}_{2}$ and $\mathrm{H}_{2} \mathrm{O}$ bands appeared in some samples and did not appear in others (FTIR analysis for all samples can be found in our previous contribution) [43].

Table 2 shows the $\mathrm{pH}_{\mathrm{ZC}}$ obtained for samples prepared under different conditions. Increasing temperature from 50 to $250{ }^{\circ} \mathrm{C}$ increased the $\mathrm{pHzc}$ of $\mathrm{ZnO}$ samples from 7.1 to 8.1. The pHzc value of 8.1 corresponds to a partially or totally dehydrated surface. An increase in the pHzc of the $\mathrm{ZnO}$ samples from 7.2 to 8.1 was achieved by increasing the synthetic $\mathrm{pH}$ value from 7 to 11 . This could be related to the effect of $\mathrm{pH}$ on the species ionization state, and accordingly, different species could be adsorbed on the $\mathrm{ZnO}$ surface. A very limited effect of precursor concentration and reaction time on the $\mathrm{pH}_{\mathrm{ZC}}$ was observed. Probably, the differences in $\mathrm{pH}_{\mathrm{ZC}}$ in this study resulted from the formation or adsorption of $\mathrm{Zn}$ hydrolytic complexes on the $\mathrm{ZnO}$ surface changing the surface stoichiometry [53]. According to the models shown in Table 3, synthesis $\mathrm{pH}$ has a significant effect on the $\mathrm{pH}_{\mathrm{ZC}}$ within the $95 \%$ confidence interval. This result is confirmed by the residual plots shown in Figure 5, with a normal probability plot (Figure 5a) and a plot of residuals with random distribution against predicted values (Figure 5b). 


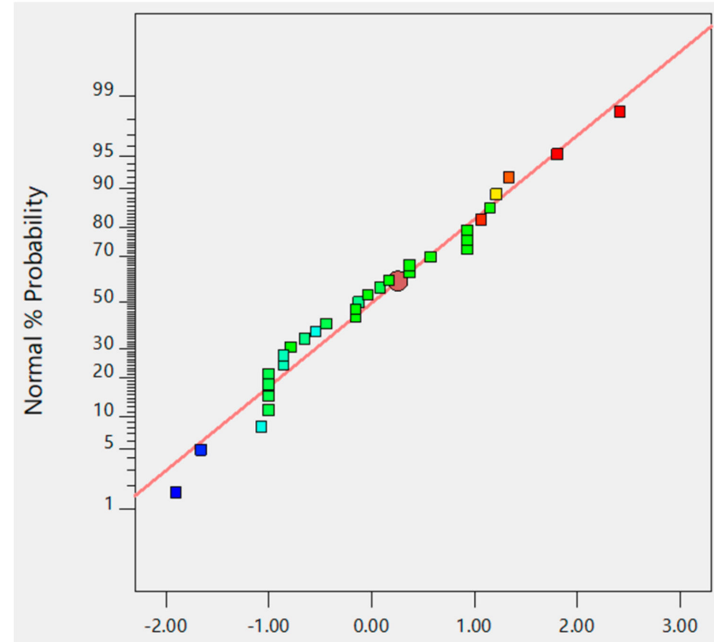

(a)

Externally Studentized Residuals

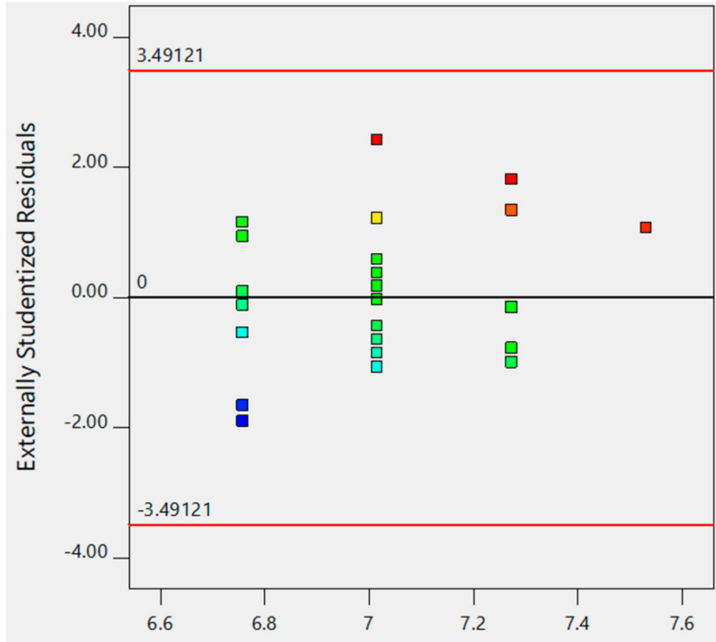

(b)

Predicted

Figure 5. Model adequacy tests for $\mathrm{pH}_{\mathrm{ZC}}$ response: Normal probability of the externally studentized residuals (a), Predicted versus externally studentized residuals $(\mathbf{b})$.

To examine the $\mathrm{MO}$ and $\mathrm{MB}$ removal efficiencies, a set of experiments was performed under the same conditions using different sample each times. It can be seen from Figure 6 that, for most of the samples, MB removal efficiency was higher than that of MO considering the formula weights of the $\mathrm{MB}=319.9 \mathrm{~g} / \mathrm{mol}$ and of the $\mathrm{MO}=327.3 \mathrm{~g} / \mathrm{mol}$, and $\mathrm{MB}$ with a smaller weight had a better diffusion rate than MO. Thus, there is an inverse relationship between the molecular weight of the dye molecules and their adsorption rates from aqueous media. Furthermore, it is very clear to observe the effect of synthesis conditions on the adsorption performance, as 100\% removal efficiency was achieved by some samples such as sample 9 and sample 30 while other samples recorded $0 \%$ removal efficiency such as sample 20. Interestingly, the samples with high adsorption efficiency were able to effectively remove both cationic (MB) and anionic (MB) dyes. On the other hand, samples with weak performance were weak toward both of the dyes as well. This is very attractive as one adsorbent can be used to adsorb cations and anions by simply controlling the surface charge of the adsorbent. The $\mathrm{pH}_{\mathrm{ZC}}$ of the samples were within a range of 5.9-8.1. Thus, when the samples are to adsorb MB, it should be used in a basic medium, i.e., $\mathrm{pH}>\mathrm{pH}_{\mathrm{ZC}}$. At such a $\mathrm{pH}$, the surface of all samples will be bearing a negative charge. Accordingly, it will attract the positively charged dye. In the case of adsorbing $\mathrm{MO}$, an acidic medium, i.e., $\mathrm{pH}<\mathrm{pH}_{\mathrm{ZC}}$, is required to ensure positively charged samples to be able to attract the negative dye.

Usually, for comparison with other adsorbents, it is more useful to study adsorption capacity of the adsorbent. Thus, similar to the removal efficiency, the adsorption capacities of all samples were calculated (Table 2) and the results are presented in Figure $6 \mathrm{~b}$. It is very clear that $q$ and $R$ have the same trend for both $\mathrm{MB}$ and $\mathrm{MO}$ since all experiments were performed under similar conditions of initial concentration, mass of adsorbent, and volume of solution. As shown in Table 2, a maximum $\mathrm{MB}$ adsorption capacity of $8 \mathrm{mg} / \mathrm{g}$ was achieved with samples 9 and 30, while, for MO, a maximum adsorption capacity of $7.66 \mathrm{mg} / \mathrm{g}$ was achieved using sample 10 .

Table 3 clearly shows that the models obtained for $\mathrm{q}_{\mathrm{MB}}$ and $\mathrm{q}_{\mathrm{MO}}$ are affected by the same factors as the models obtained for $\mathrm{R}_{\mathrm{MB}}$ and $\mathrm{R}_{\mathrm{MO}}$. The main factor affecting the adsorption capacity of $\mathrm{MB}$ is temperature, while, for $\mathrm{MO}$, temperature, $\mathrm{pH}$, and reaction time are important factors. This result is confirmed by the residual plots shown in Figure S4, with a normal probability plot and a plot of residuals with random distribution against predicted values. 

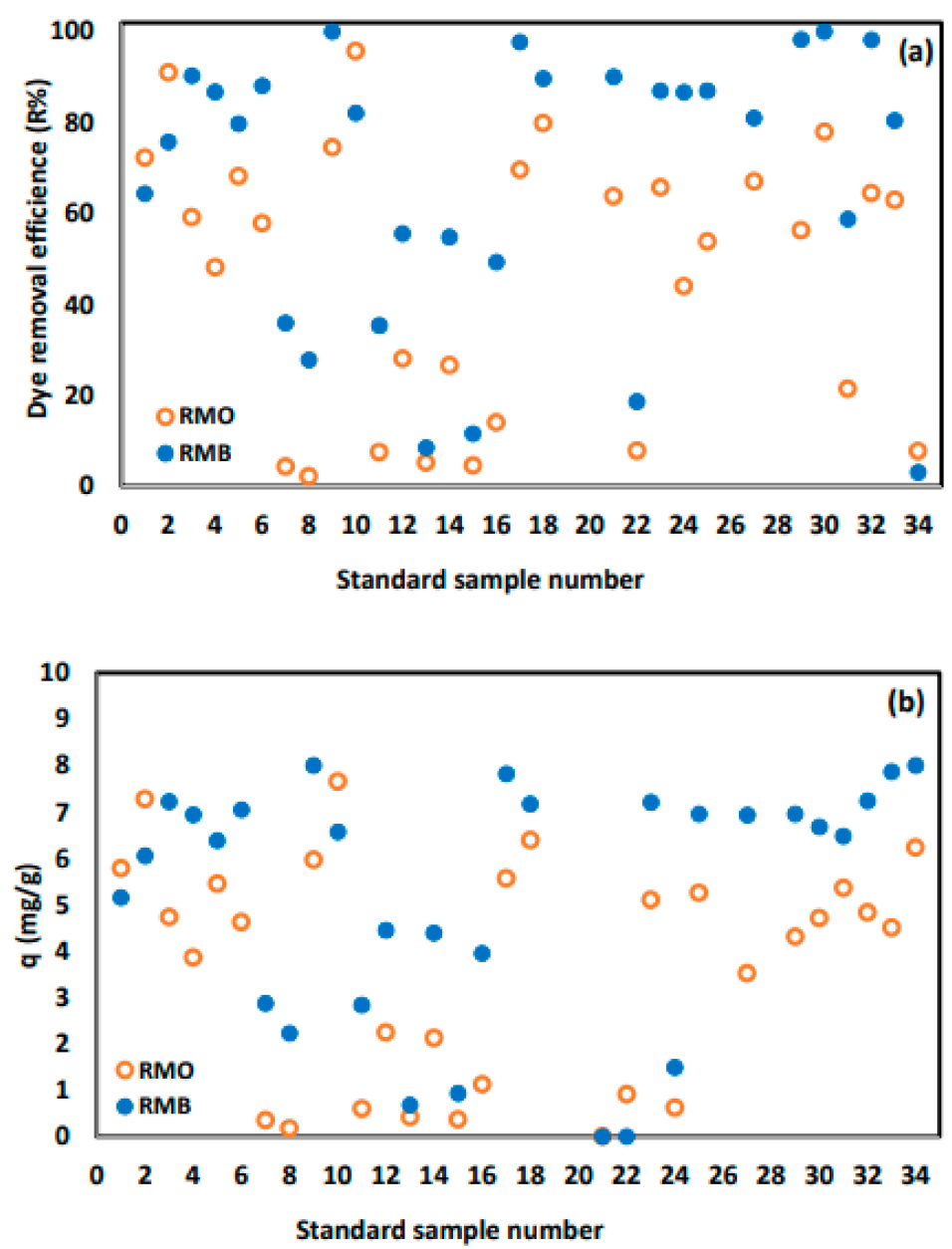

Figure 6. (a) Removal efficiencies (R) and (b) adsorption capacities (q) of MO and MB by adsorption on the 34 prepared $\mathrm{ZnO}$ samples.

Table 4 summarizes some contributions in the literature for the adsorption of $\mathrm{MB}$ and $\mathrm{MO}$ on $\mathrm{ZnO}$. It is not easy to compare the results obtained because of the variation of adsorption conditions used. However, the results obtained in this work are very attractive, as they show a high removal efficiency (100\%) at a low concentration, implying that samples 10 and 29 are very promising for such an application.

Table 4. Adsorption of $\mathrm{MB}$ and $\mathrm{MO}$ by $\mathrm{ZnO}$ reported in the literature.

\begin{tabular}{cccc}
\hline Adsorbate & Adsorption Conditions & $\mathbf{q} \mathbf{( m g} / \mathbf{g})$ & Reference \\
\hline $\mathrm{MB}$ & $\mathrm{pH}=6, \mathrm{~m}=0.5 \mathrm{~g}$, initial concentration $(\mathrm{Ci})=40 \mathrm{ppm}$ & 34.19 & {$[37]$} \\
$\mathrm{MB}$ & $\mathrm{V} / \mathrm{m}=0.625 \mathrm{~L} / \mathrm{g}, \mathrm{Ci}=50 \mathrm{ppm}$ & 27.45 & {$[38]$} \\
$\mathrm{MB}$ & $\mathrm{V} / \mathrm{m}=10 \mathrm{~L} / \mathrm{g}, \mathrm{pH}=6, \mathrm{Ci}=100 \mathrm{ppm}$ & 198 & {$[39]$} \\
$\mathrm{MB}$ & $\mathrm{V} / \mathrm{m}=1 \mathrm{~L} / \mathrm{g}, \mathrm{pH}=6, \mathrm{Ci}=10 \mathrm{mmol} / \mathrm{L}$ & $7 \mathrm{mmol} / \mathrm{g}$ & {$[40]$} \\
$\mathrm{MB}$ & $\mathrm{V} / \mathrm{m}=0.5 \mathrm{~L} / \mathrm{g}, \mathrm{Ci}=16 \mathrm{ppm}$ & 7.67 & {$[41]$} \\
$\mathrm{MO}$ & $\mathrm{V} / \mathrm{m}=2 \mathrm{~L} / \mathrm{g}, \mathrm{pH}=6.5, \mathrm{Ci}=50 \mathrm{ppm}$ & 11 & {$[42]$} \\
$\mathrm{MB}$ & $\mathrm{V} / \mathrm{m}=0.4 \mathrm{~L} / \mathrm{g}, \mathrm{pH}=8, \mathrm{Ci}=20 \mathrm{ppm}$ & 7.86 & Current work (sample 29) \\
$\mathrm{MO}$ & $\mathrm{V} / \mathrm{m}=0.4 \mathrm{~L} / \mathrm{g}, \mathrm{pH}=4.5, \mathrm{Ci}=20 \mathrm{ppm}$ & 7.66 & Current work (sample 10) \\
\hline
\end{tabular}

The models given in Table 3 show that $\mathrm{R}_{\mathrm{MB}}$ depends on the synthesis temperature within the $95 \%$ confidence interval used, while $\mathrm{R}_{\mathrm{MO}}$ depends on temperature, $\mathrm{pH}$, and reaction time.

The respective $R_{M O}$ and $R_{M B} F$ values of 23.3 and 14.77 (Table 3) imply that the models are significant with a chance less than $0.1 \%$ and these values are large due to noise. Furthermore, for both 
models, the residuals $\mathrm{F}$ values are 5.91 and 7.338 for $\mathrm{MO}$ and $\mathrm{MB}$, respectively, with $P$-values higher than $5 \%$, confirming that residuals are $15.48 \%$ for $\mathrm{MO}$ and $10.94 \%$ for $\mathrm{MB}$ due to noise, confirming the model adequacy. Residuals plots are shown in Figure 7a,b for $R_{M B}$ and in Figure $7 c, d$ for $R_{M O}$. There is no doubt that the models are correct since the normal probability plots are linear and the plots of residuals against predicted values do not follow any pattern.

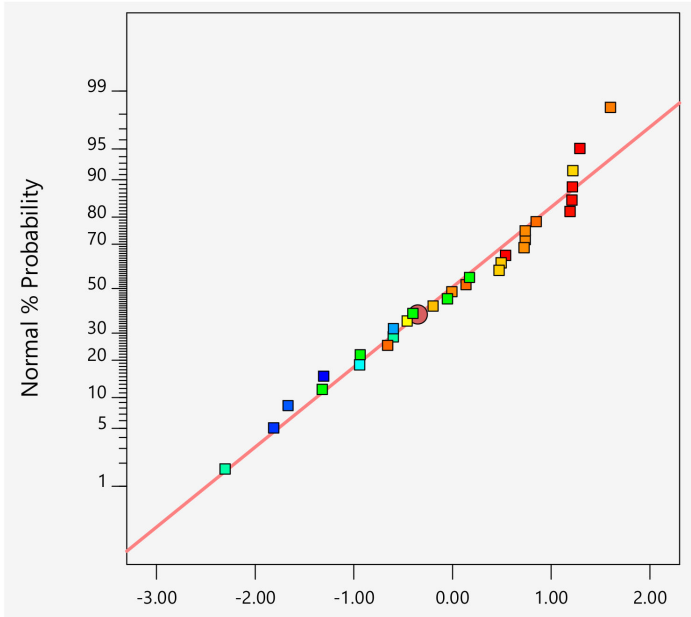

(a)

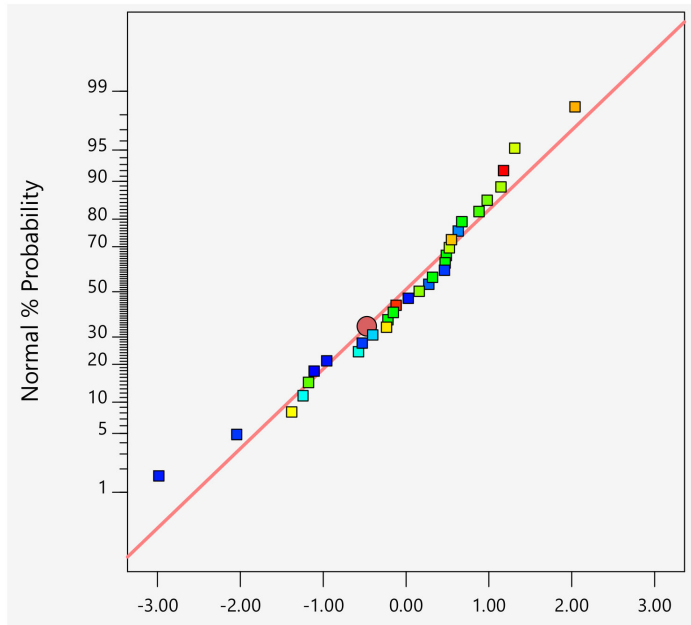

(c)

Externally Studentized Residuals

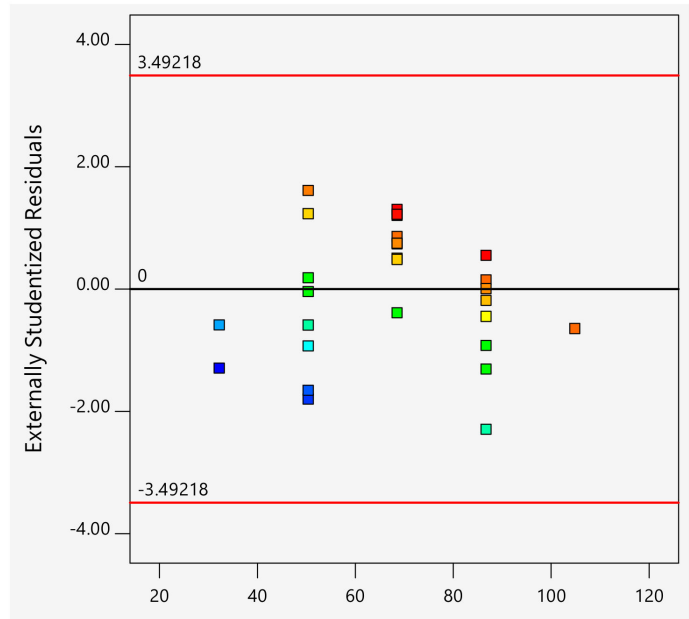

(b)

Predicted

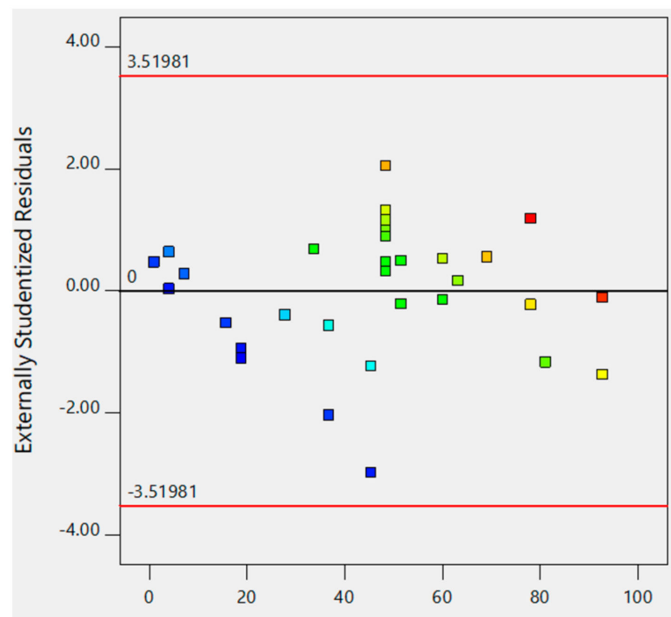

(d)

Predicted

Figure 7. Model adequacy tests for $\mathrm{R}_{\mathrm{MO}}$ response: Normal probability of the externally studentized residuals (a), Predicted versus externally studentized residuals (b). Model adequacy tests for $R_{M B}$ response: Normal probability of the externally studentized residuals (c), Predicted versus externally studentized residuals $(\mathbf{d})$.

\section{Conclusions}

$\mathrm{ZnO}$ nanoparticles were synthesized via a hydrothermal technique under different conditions following surface composite design methodology. The main responses tested within the $95 \%$ confidence interval were the ability of the synthesized $\mathrm{ZnO}$ to adsorb the $\mathrm{MO}$ cationic dye and the $\mathrm{MB}$ anionic dye from aqueous solutions, the $\mathrm{pH}_{\mathrm{ZC}}$ of the adsorbent, and the average particle size of $\mathrm{ZnO}$. The $\mathrm{ZnO}$ formation was confirmed by the XRD, UV-VIS, and FTIR spectra via the appearance of the ZnO characteristic peaks. Adsorption results showed an excellent performance of some samples with a removal efficiency of up to $100 \%$ for $\mathrm{MB}$ and a maximum removal efficiency of $96 \%$ for $\mathrm{MO}$, which demonstrated that an excellent candidate can be provided for removal of both dyes. $\mathrm{R}_{\mathrm{MO}}$ shows 
a dependency on $\mathrm{T}, \mathrm{pH}$, and $\mathrm{t}$, while $\mathrm{R}_{\mathrm{MB}}$ depends only on $\mathrm{T}$. The estimated $\mathrm{D}_{\mathrm{h}}$ obtained by DLS varied within a range of $218-8920 \mathrm{~nm}$ because of changing synthesis conditions. According to the model, the $\mathrm{D}_{\mathrm{h}}$ was affected mostly by the substrate concentration and synthesis $\mathrm{pH}$. A wide range of $\mathrm{pH}_{\mathrm{ZC}}$ (5.9-8.1) was obtained for the samples, which gives the samples a diverse range of adsorption applications for both cationic and anionic species. The $\mathrm{pH}_{\mathrm{ZC}}$ model indicated the dependency on synthesis $\mathrm{pH}$ at the $95 \%$ confidence interval used.

Supplementary Materials: The following are available online at http://www.mdpi.com/1420-3049/24/21/3884/s1.

Author Contributions: M.M.K. performed the experiments and reviewed the manuscript; E.D. conceived, designed, performed the experiments, analyzed the results, wrote, reviewed, and checked the English grammars in manuscript; K.A.-A. contributed in the experimental work; M.H. conceived, designed, performed the experiments, built the models, analyzed the results; reviewed and checked the English grammars in manuscript.

Funding: This research and the APC were funded by the Deanship of Scientific Research, King Faisal University, grant number 186096.

Acknowledgments: This work was supported by the grants from the Deanship of Scientific Research, King Faisal University, Saudi Arabia (No. 186096). The financial contribution is gratefully acknowledged.

Conflicts of Interest: The authors declare no conflict of interest.

\section{References}

1. Duo, S.; Li, Y.; Liu, Z.; Zhong, R.; Liu, T. Novel hybrid self-assembly of an ultralarge ZnO macroflower and defect intensity-induced photocurrent and photocatalytic properties by facile hydrothermal synthesis using CO(NH2)2-N2H4 as alkali sources. Mater. Sci. Semicond. Process. 2016, 56, 196-212. [CrossRef]

2. Bisht, G.; Rayamajhi, S. ZnO Nanoparticles: A Promising Anticancer Agent. Nanobiomedicine 2016, 3, 9. [CrossRef] [PubMed]

3. Andrade, G.R.; Nascimento, C.C.; Lima, Z.M.; Costa, L.P.; Gimenez, I.F.; Teixeira-Neto, E. Star-shaped $\mathrm{ZnO} / \mathrm{Ag}$ hybrid nanostructures for enhanced photocatalysis and antibacterial activity. Appl. Surf. Sci. 2017, 399, 573-582. [CrossRef]

4. Fiedot, M.; Maliszewska, I.; Rac-Rumijowska, O.; Suchorska-Woźniak, P.; Lewińska, A.; Teterycz, H. The Relationship between the Mechanism of Zinc Oxide Crystallization and Its Antimicrobial Properties for the Surface Modification of Surgical Meshes. Materials 2017, 10, 353. [CrossRef]

5. Ali, T.T.; Narasimharao, K.; Parkin, I.P.; Carmalt, C.J.; Sathasivam, S.; Basahel, S.N.; Bawaked, S.M.; Al-Thabaiti, S.A. Effect of pretreatment temperature on the photocatalytic activity of microwave irradiated porous nanocrystalline ZnO. New J. Chem. 2015, 39, 321-332. [CrossRef]

6. Anandan, M.; Dinesh, S.; Krishnakumar, N.; Balamurugan, K. Tuning the crystalline size of template free hexagonal $\mathrm{ZnO}$ nanoparticles via precipitation synthesis towards enhanced photocatalytic performance. J. Mater. Sci. Mater. Electron. 2017, 28, 2574-2585. [CrossRef]

7. Tabib, A.; Bouslama, W.; Sieber, B.; Addad, A.; Elhouichet, H.; Férid, M.; Boukherroub, R. Structural and optical properties of Na doped ZnO nanocrystals: Application to solar photocatalysis. Appl. Surf. Sci. 2017, 396, 1528-1538. [CrossRef]

8. Jo, W.; Tayade, R.J. New Generation Energy-E ffi cient Light Source for Photocatalysis: LEDs for Environmental Applications. Ind. Eng. Chem. Res. 2014, 53, 2073-2084. [CrossRef]

9. Molla, M.A.I.; Tateishi, I.; Furukawa, M.; Katsumata, H.; Suzuki, T.; Kaneco, S. Photocatalytic Decolorization of Dye with Self-Dye-Sensitization under Fluorescent Light Irradiation. ChemEngineering 2017, 1, 8. [CrossRef]

10. Bhakat, C.; Singh, P.P. Zinc Oxide Nanorods: Synthesis and Its Applications in Solar Cell. Int. J. Mod. Eng. Res. 2012, 2, 2452-2454.

11. Oprea, O.; Andronescu, E.; Ficai, D.; Ficai, A.; Oktar, F.; Yetmez, M. ZnO Applications and Challenges. Curr. Org. Chem. 2014, 18, 192-203. [CrossRef]

12. Sun, Y.; Guo, H.; Zhang, W.; Zhou, T.; Qiu, Y.; Xu, K.; Zhang, B.; Yang, H. Synthesis and characterization of twinned flower-like $\mathrm{ZnO}$ structures grown by hydrothermal methods. Ceram. Int. 2016, 42, 9648-9652. [CrossRef]

13. Joo, J.; Chow, B.Y.; Prakash, M.; Boyden, E.S.; Jacobson, J.M. Face-selective electrostatic control of hydrothermal zinc oxide nanowire synthesis. Nat. Mater. 2011, 10, 596-601. [CrossRef] [PubMed] 
14. Khanlary, M.R.; Vahedi, V.; Reyhani, A. Synthesis and Characterization of ZnO Nanowires by Thermal Oxidation of Zn Thin Films at Various Temperatures. Molecules 2012, 17, 5021-5029. [CrossRef]

15. Liang, Y.; Wicker, S.; Wang, X.; Erichsen, E.; Fu, F. Organozinc Precursor-Derived Crystalline ZnO Nanoparticles: Synthesis, Characterization and Their Spectroscopic Properties. Nanomaterials 2018, 8, 22. [CrossRef]

16. Moezzi, A.; Cortie, M.; McDonagh, A. Aqueous pathways for the formation of zinc oxide nanoparticles. Dalt. Trans. 2011, 40, 4871. [CrossRef]

17. Zaid, M.H.M.; Matori, K.A.; Aziz, S.H.A.; Zakaria, A.; Ghazali, M.S.M. Effect of ZnO on the Physical Properties and Optical Band Gap of Soda Lime Silicate Glass. Int. J. Mol. Sci. 2012, 13, 7550-7558. [CrossRef]

18. Kavitha, M.; Saroja, M.; Kumar, V.R.; Jenifer, G. Particle Size Analysis for Different Substrate of ZnS/ZnO Thin Film in CBD Technique. Int. J. Thin Films Sci. Technol. 2016, 5, 137-141. [CrossRef]

19. Zak, A.K.; Razali, R.; Majid, W.A.; Darroudi, M. Synthesis and characterization of a narrow size distribution of zinc oxide nanoparticles. Int. J. Nanomed. 2011, 6, 1399-1403.

20. Balogun, S.W.; Sanusi, Y.K.; Aina, A.O. Impact of Post-Deposition Heat Treatment on the Morphology and Optical Properties of Zinc Oxide ( $\mathrm{ZnO})$ Thin Film Prepared by Spin-Coating Technique. J. Photon. Mater. Technol. 2017, 3, 20. [CrossRef]

21. Matei, A.; Tucureanu, V.; Dumitrescu, L. Aspects Regarding Synthesis And Applications Of ZnO. Bull. Transilv. Univ. Brasov. Eng. Sci. 2014, 7, 45-52.

22. Tombácz, E. Ph-dependent surface charging of metal oxides. Period. Polytech. Chem. Eng. 2009, 53, 77-86. [CrossRef]

23. Sathya, M.; Claude, A.; Govindasamy, P.; Sudha, K.; Claude, A. Growth of pure and doped ZnO thin films for solar cell applications. Pelagia Res. Libr. Adv. Appl. Sci. Res. 2012, 3, 2591-2598.

24. Montgomery, D.C. Design and Analysis of Experiments, 9th ed.; John Wiley \& Sons: Phoenix, AZ, USA, 2017.

25. Prouzet, E.; Hessien, M.; Singh, N.; Kim, C. Stability and tunability of O/W nanoemulsions prepared by phase inversion composition. Langmuir 2011, 27, 2299-2307.

26. Hossini, H.; Safari, M.; Rezaee, R.; Darvishi, R.; Soltani, C. Application of experimental design approach for optimization of the photocatalytic degradation of humic substances in aqueous solution using immobilized ZnO nanoparticles. J. Adv. Environ. Health Res. 2015, 3, 154-163.

27. Ibupoto, Z.H.; Khun, K.; Eriksson, M.; AlSalhi, M.; Atif, M.; Ansari, A.; Willander, M. Hydrothermal Growth of Vertically Aligned ZnO Nanorods Using a Biocomposite Seed Layer of ZnO Nanoparticles. Materials 2013, 6, 3584-3597. [CrossRef]

28. Lu, C.; Yeh, C. Influence of hydrothermal conditions on the morphology and particle size of zinc oxide powder. Ceram. Int. 2000, 26, 351-357. [CrossRef]

29. Kumar, D.; Dubey, K.K. Optimization of Zinc Oxide nanoparticles synthesis to fabricate glucose oxidase sensor. Pelagia Res. Libr. 2012, 3, 3081-3088.

30. Lee, K.M.; Hamid, S.B.A. Simple Response Surface Methodology: Investigation on Advance Photocatalytic Oxidation of 4-Chlorophenoxyacetic Acid Using UV-Active ZnO Photocatalyst. Materials 2015, 8, 339-354. [CrossRef]

31. Xu, S.; Adiga, N.; Ba, S.; Dasgupta, T.; Wu, C.F.J.; Wang, Z.L. Optimizing and Improving the Growth Quality of ZnO Nanowire Arrays Guided by Statistical Design of Experiments. ACS Nano 2009, 3, 1803-1812. [CrossRef]

32. Jain, R.; Sikarwar, S. Photocatalytic and adsorption studies on the removal of dye Congo red from wastewater. Int. J. Environ. Pollut. 2006, 27, 158. [CrossRef]

33. Darvishi, R.; Cheshmeh, S.; Rezaee, A.; Rezaee, R.; Safari, M. Photocatalytic degradation of methylene blue dye over immobilized $\mathrm{ZnO}$ nanoparticles: Optimization of calcination conditions. J. Adv. Environ. Health Res. 2015, 3, 1-7.

34. Ali, A.H.; Naser, G.F.; Mohammed, S.A. Photocatalytic Degradation of Methyl Orange Dye using Different Photocatalysts under Solar Light. Int. J. ChemTech. Res. 2016, 9, 157-165.

35. Chebor, L.J. Characterization of Synthesized ZnO Nanoparticles and their Application in Photodegradation of Methyl Orange Dye Under Fluorescent Lamp Irradiation. Int. J. Sci. Eng. Sci. 2018, 2, 5-8.

36. Sani, H.A.; Aliyu, H.S.; Tukur, S.A. Methylene Blue Dye Adsorption Using a Polymer Coated ZnO with Chitosan Nano-Catalyst. J. Appl. Chem. 2015, 8, 34-38.

37. Saleh, K.A.; Al-taie, H.H. Methylene Blue Adsorption Study Using Different Zno Types ( Normal, Shaheed Factory, Nano ). Int. J. Sci. Res. 2017, 6, 939-944. 
38. Kulkarni, J.C.A.V.; Chavhan, A.; Bappakhane, A. Chimmankar ZnO Nanoparticles as Adsorbent for Removal of Methylene Blue dye. Res. J. Chem. Environ. Sci. 2016, 4, 158-163.

39. Zhang, F.; Lan, J.; Yang, Y.; Wei, T.; Tan, R.; Song, W. Adsorption behavior and mechanism of methyl blue on zinc oxide nanoparticles. J. Nanoparticle Res. 2013, 15, 2034. [CrossRef]

40. Al-Khateeb, I.; Mahmood, M. Adsorption, Thermodynamics and Kinetics of Methylene Blue on Nano Structured ZnO Crystals. Am. Chem. Sci. J. 2016, 13, 1-9. [CrossRef]

41. Tajizadegan, H.; Jafari, M.; Rashidzadeh, M.; Saffar-Teluri, A. A high activity adsorbent of $\mathrm{ZnO}_{-} \mathrm{Al}_{2} \mathrm{O}_{3}$ nanocomposite particles: Synthesis, characterization and dye removal efficiency. Appl. Surf. Sci. 2013, 276, 317-322. [CrossRef]

42. Hessien, M.; Da'Na, E.; Al-Amer, K.; Khalaf, M.M.; D’Na, E. Nano ZnO (hexagonal wurtzite) of different shapes under various conditions: Fabrication and characterization. Mater. Res. Express 2019, 6, 085057. [CrossRef]

43. Da'Na, E.; Sayari, A. Adsorption of copper on amine-functionalized SBA-15 prepared by co-condensation: Equilibrium properties. Chem. Eng. J. 2011, 166, 445-453. [CrossRef]

44. Moharram, A.H.; Mansour, S.A.; Hussein, M.A.; Rashad, M. Direct Precipitation and Characterization of ZnO Nanoparticles. J. Nanomater. 2014, 2014, 1-5. [CrossRef]

45. Bodke, M.R.; Purushotham, Y.; Dole, B.N. Comparative study on zinc oxide nanocrystals synthesized by two precipitation methods. Cerâmica 2018, 64, 91-96. [CrossRef]

46. Sotomayor, F.J.; Cychosz, K.A.; Thommes, M.; Sotomayor, F. Characterization of Micro / Mesoporous Materials by Physisorption: Concepts and Case Studies. Acc. Mater. Surf. Res. 2018, 3, 34-50.

47. Ravikovitch, P.I.; Neimark, A.V. Diffusion-Controlled Hysteresis. Adsorption 2005, 11, 265-270. [CrossRef]

48. Zhang, H.; Yang, D.; Ma, X.; Ji, Y.; Xu, J.; Que, D. Synthesis of flower-like ZnO nanostructures by an organic-free hydrothermal process. Nanotechnology 2004, 15, 622-626. [CrossRef]

49. Jiang, L.; Li, G.; Ji, Q.; Peng, H. Morphological control of flower-like ZnO nanostructures. Mater. Lett. 2007, 61, 1964-1967. [CrossRef]

50. Shi, R.; Yang, P.; Dong, X.; Ma, Q.; Zhang, A. Growth of flower-like ZnO on ZnO nanorod arrays created on zinc substrate through low-temperature hydrothermal synthesis. Appl. Surf. Sci. 2013, 264, 162-170. [CrossRef]

51. Raoufi, D. Synthesis and microstructural properties of $\mathrm{ZnO}$ nanoparticles prepared by precipitation method. Renew. Energy 2013, 50, 932-937. [CrossRef]

52. Stankovic, J.; Milonjic, S.; Zec, S. The influence of chemical and thermal treatment on the point of zero charge of hydrous zirconium oxide. J. Serbian Chem. Soc. 2013, 78, 987-995. [CrossRef]

53. Ocholi, O.J.; Gimba, C.E.; Ndukwe, G.I.; Turoti, M.; Abechi, S.E.; Edogbanya, P.R.O. Effect of Time on the Adsorption of Methylene Blue, Methyl Orange and Indigo Carmine onto Activated Carbon. J. Appl. Chem. 2016, 9, 55-62.

Sample Availability: Samples of the compounds are not available from the authors.

(C) 2019 by the authors. Licensee MDPI, Basel, Switzerland. This article is an open access article distributed under the terms and conditions of the Creative Commons Attribution (CC BY) license (http://creativecommons.org/licenses/by/4.0/). 